\title{
Development of the PKX myxosporean in rainbow trout Salmo gairdneri
}

\author{
Michael L. Kent* \& Ronald P. Hedrick** \\ Department Medicine, School of Veterinary Medicine, University of California, Davis, California 95616, USA
}

\begin{abstract}
Sequential development of PKX, the causative agent of proliferative kidney disease ${ }_{r}$ is described in rainbow trout Salmo gairdneri Richardson by light and electron microscopy. Fish were exposed to water containing the infectious stage of PKX and the parasite was detected 3 wk later. Parasites were prominent the following week and they multiplied by endogeny, binary fission and possibly plasmotomy in the blood and kidney interstitium. Interstitial nephritis that is typically associated with PKD was first observed $5 \mathrm{wk}$ after exposure and was most prominent between 8 to $11 \mathrm{wk}$. At $7 \mathrm{wk}$, parasites were found in the lumens of the tubules; many were daughter cells released from PKX. Myxosporean sporoblasts formed within these daughter cells (enveloping cells). The sporoblasts consisted of 6 cells and some organized into spores with 2 spherical polar capsules. Although the spores persisted for several months after the interstitial PKX and associated inflammation had subsided, they did not complete their development. They remained within the enveloping cell and apparently did not form complete valves. Because only incomplete spores were observed, salmonids may be abnormal hosts and the precise taxonomic status of PKX was not determined. Epizootiological and sequential development data support the hypothesis that the interstitial form of PKX and the intraluminal myxosporeans belong to the same organism.
\end{abstract}

\section{INTRODUCTION}

Proliferative kidney disease (PKD), caused by an unclassified protozoan (PKX), is considered a serious obstacle to the successful culture of certain salmonid fishes. The disease has been reported most often in rainbow trout Salmo gairdneri Richardson, and mortalities may reach $90 \%$, but usually remain below 30 to $50 \%$ (Clifton-Hadley et al. 1984). Other salmonid species have been affected and PKD is considered one of the most important diseases of cultured salmonids in Europe (Clifton-Hadley et al. 1984). It is also widespread in western North America (Hedrick et al. 1984a, b, 1985; Smith et al. 1984, Hoskins 1985). Even in the absence of high mortality, morbidity may be $100 \%$ and fish with PKD often exhibit decreased food conversion, poor tolerance to stress, and greater susceptibility to secondary infection (Clifton-Hadley et al. 1984). The disease inflicts additional economic burdens on production facilities because husbandry practices must be

\footnotetext{
- Present address: Center for Marine Disease Control, Battelle Marine Research Laboratory, 439 West Sequim Bay Road, Sequim, Washington 98382, USA

- Addressee for reprint requests
}

modified and the planting of exposed fishes is often restricted by regulatory agencies.

The disease is characterized by chronic inflammation of the kidney. Tissue sections reveal the PKX protozoan primarily in the kidney interstitium, associated with a granulomatous interstitial nephritis and tubular atrophy (Ferguson \& Needham 1978, CliftonHadley et al. 1984, Smith et al. 1984). In heavily infected fish, PKX is often found in the spleen, gut, gills, liver and muscle, where it also invokes a granulomatous response (Ferguson \& Needham 1978 Smith et al. 1984). The PKX parasite most likely reaches these organs via the circulatory system and may adhere to vessel walls, provoking a necrotizing vasculitis (Smith et al. 1984). If fish survive PKD, the interstitial hyperplasia subsides in 12 to $20 \mathrm{wk}$, and the kidneys of recovered fish show little if any signs of previous infection (Clifton-Hadley et al. 1985).

A parasite that was most likely PKX was described as an amoeba by Plehn (1924). Ghittino et al. (1977) and Ferguson \& Needham (1978) also suggested that PKX may be an amoeba because it formed pseudopodia. Although no spores were observed, Seagrave et al. (1980a) proposed that the organism might be a haplosporidan (phylum Ascetospora). Division by internal 
cleavage, the presence of multivesicular bodies, and the existence of electron-dense cytoplasmic inclusions reminiscent of the haplosporosomes of Marteilia spp. were cited as common features with PKX.

However, internal cleavage and organelles similar to haplosporosomes also occur among members of the Myxozod (Current \& Janovy 1977, Desser and Paterson 1978, Current et al. 1979, Lom et al. 1982, Desser et al. 1983), and Ferguson \& Needham (1978) and Seagrave et al. (1980a, b) did not exclude the possibility that PKX might belong to this phylum. Hedrick et al. (1984b) and Kent \& Hedrick (1985a) observed myxosporean trophozoites and developing spores in the renal tubules of fish with $\mathrm{PKD}$, and they proposed that the observed organisms might be later stages of PKX and that PKX belongs most appropriately to the phylum Myxozoa.

We present here a detailed description of the sequential development of PKX from the renal intersti- tial form (typical $\mathrm{PKX}$ ) to an immature myxosporean spore in the lumens of the tubules. We also present evidence that substantiates that both forms belong to the same organism. These findings indicate that PKX is a member of the phylum Myxozoa.

\section{MATERIALS AND METHODS}

A group of PKX-free rainbow trout under 1 yr of age (Eagle Lake, California strain) was introduced into water containing the infective stage of $\mathrm{PKX}$ at the American River hatchery, Rancho Cordova, California, USA on 16 August 1984. The parasite is only transmitted by water-borne exposure or by injecting infected tissues (D'Silva et al. 1984), and the infective stage under natural conditions is yet to be identified. Approximately 500 of these fish were transferred to the Fish Pathology Laboratory at the University of Califor-

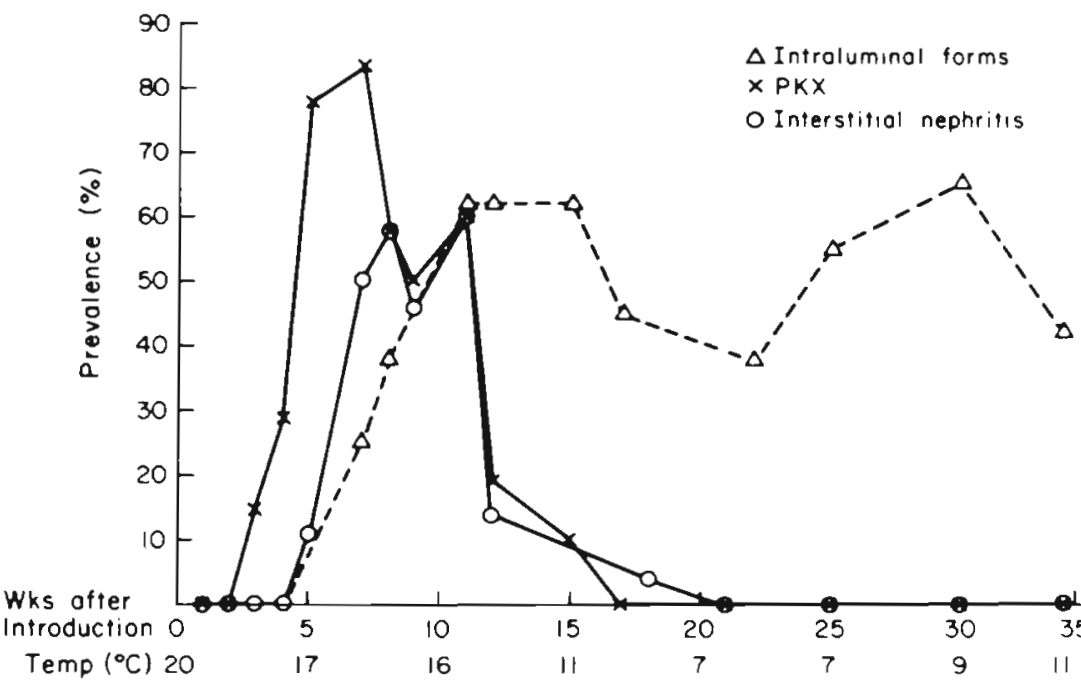

Fig. 1. Salmo gairdneri. Sequential prevalence of interstitial PKX, intraluminal sporogonic forms and interstitial inflammation in the kidneys of rainbow trout maintained at the American River hatchery. Samples of 15 to 30 fish were taken periodically from Aug 1984 through Apr 1985

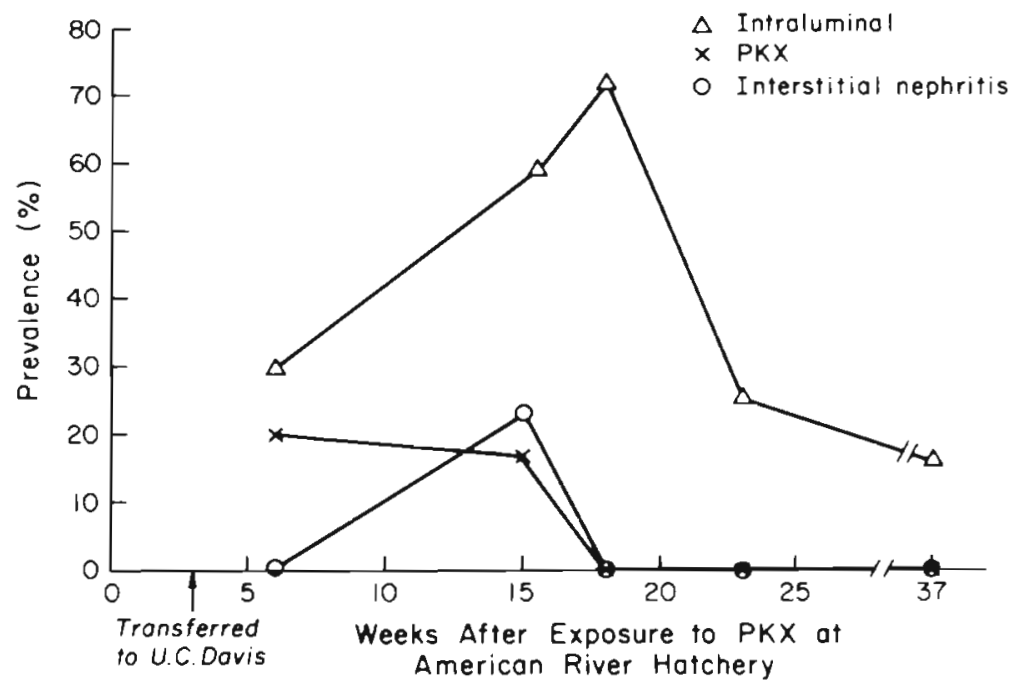

Fig. 2. Salmo gairdneri. Sequential prevalence of interstitial PKX, intraluminal sporogonic forms and interstitial inflammation in the kidneys of rainbow trout at the U.C. Davis fish pathology laboratory. Approximately 500 fish exposed to PKX at the American River hatchery were transferred to the laboratory on 9 Sep 1985 and 15 to 30 fish samples were taken periodically through Apr 1985 
nia (U.C.), Davis, California, on 9 September 1984 and maintained in PKX-free well water at 15 to $18^{\circ} \mathrm{C}$. Samples of 15 to 30 fish were taken at selected times from the population at the hatchery and from the fish at U.C. Davis until May 1985.

To determine the morphology of PKX, preparations of fresh kidney were squashed between a cover slip and glass slide (wet mounts), and then examined by bright field and phase contrast microscopy. For histological examinations, tissues were fixed in Davidson's solution, embedded in paraffin, sectioned at $5 \mu \mathrm{m}$, and stained with either hematoxylin and eosin (H \& E) or Prices's Giemsa as described by Luna (1968) and Humason (1979). Fish from the sequential samples taken at the American River hatchery and U.C. Davis were examined for the prevalence of interstitial PKX, associated pathology, and intraluminal myxosporean stages using paraffin sections of the kidneys. Kidney tissue samples for electron microscopy were fixed in $3 \%(\mathrm{v} / \mathrm{v})$ glutaraldehyde in phosphate buffer as described by Bullock (1978). These specimens were post-fixed in $1 \% \mathrm{OsO}_{4}$, embedded in Epon, sectioned, stained with lead citrate and uranyl acetate, and examined with a Phillips EM 400 transmission electron microscope. Similar developmental stages of PKX were observed in all epizootics of PKD in California, and fish from several locations in the state were used for the light and electron microscopical descriptions.

\section{RESULTS}

\section{Temporal prevalence}

The PKX parasite was first detected in one of 15 fish examined 3 wk after transfer to the American River hatchery (Fig. 1). Parasites were easily detected the following week and reached a peak prevalence of $83 \%$ at $7 \mathrm{wk}$. Associated interstitial inflammation was evident at $5 \mathrm{wk}$, and was most prominent between 8 and 11 wk. The PKX parasite in the epithelium of the tubules and intraluminal sporogonic stages were first detected at $7 \mathrm{wk}$. These forms persisted at approximately the same prevalence for at least $12 \mathrm{wk}$ after interstitial PKX and associated lesions were no longer detectable (Fig. 1). However, the intensity of the intraluminal sporogonic forms diminished with time. The prevalence of intraluminal forms increased and interstitial PKX and associated lesions decreased as the water temperature at the hatchery declined (Fig. 1).

The development of PKX in the fish transferred to U.C. Davis was similar to that observed in the fish held at the hatchery (Fig. 2). However, even though the temperature at U.C. Davis was above $15{ }^{\circ} \mathrm{C}$ throughout the study, the intraluminal forms became prevalent in these fish as the disease progressed (Fig. 2).

\section{Light microscopy}

The organism seen at 3 wk was small, condensed, eosinophilic, and contained a daughter cell (Fig. 3). Tissue sections revealed larger, typical parasites in the blood and kidney interstitium the following week (Fig. 4). These forms were also detected in blood smears at this time. Primary cells with as many as 7 daughter cells were evident in these tissues (Fig. 5), and were weakly eosinophilic compared to the surrounding host cells. The nuclei of the parasites contained large endosomes that were particularly prominent in the primary cells. Degenerating primary cells and small condensed cells were observed in the interstitium of some fish. The small cells may represent released daughter cells (Fig. 6).

Parasites that were in the blood occasionally formed thrombi in the renal vessels (Fig. 7). Hypercellularity of the kidney interstitium due to mononuclear cell proliferation and infiltration was associated with the parasites (Fig. 8), and infected fish exhibited a reduced number of tubules $\mathrm{mm}^{-2}$ when compared with uninfected fish (Fig. 9). Many parasites were surrounded by attached macrophages and lymphocytes (Fig. 6). Although most fish in our experiment exhibited gross kidney hypertrophy, they did not exhibit other clinical signs of PKD and no significant mortality could be directly attributed to PKX.

Organisms with typical PKX morphology were observed in the epithelium of the renal tubules (Fig. 10), and the daughter cell of one was seen in binary fission (Fig. 11). Some primary cells in the epithelium degenerated, and their daughter cells, surrounded by primary cell remnants, migrated to the lumen (Fig. 12). Small, condensed eosinophilic cells, presumably released daughter cells, were observed in the lumen of tubules at this time. The simplest intraluminal forms were uninucleate cells that resembled the secondary cells of interstitial PKX (Fig.13). More complex intraluminal forms contained secondary and tertiary daughter cells. Continued development of these stages by endogeny and binary fission resulted in sporoblasts with up to 6 internal sporogonic cells (Fig. 14\& 15).

Developing myxosporean spores as evidenced by polar capsule formation were observed in the more advanced intraluminal parasites (Fig. 16 to 18). These spores were oblong, $12 \times 7 \mu \mathrm{m}$, with 2 spherical polar capsules $2 \mu \mathrm{m}$ in diameter (measured from wet mounts, $\mathbf{n}=20$ ). Capsulogenic nuclei and a large sporoplasm nucleus were prominent in paraffin sections stained with hematoxylin and eosin (Fig. 16). The intraluminal organisms were considered to be myxosporean trophozoites because they formed multicellular spores with polar capsules. Only one spore developed within each enveloping cell and no large multinucleated 

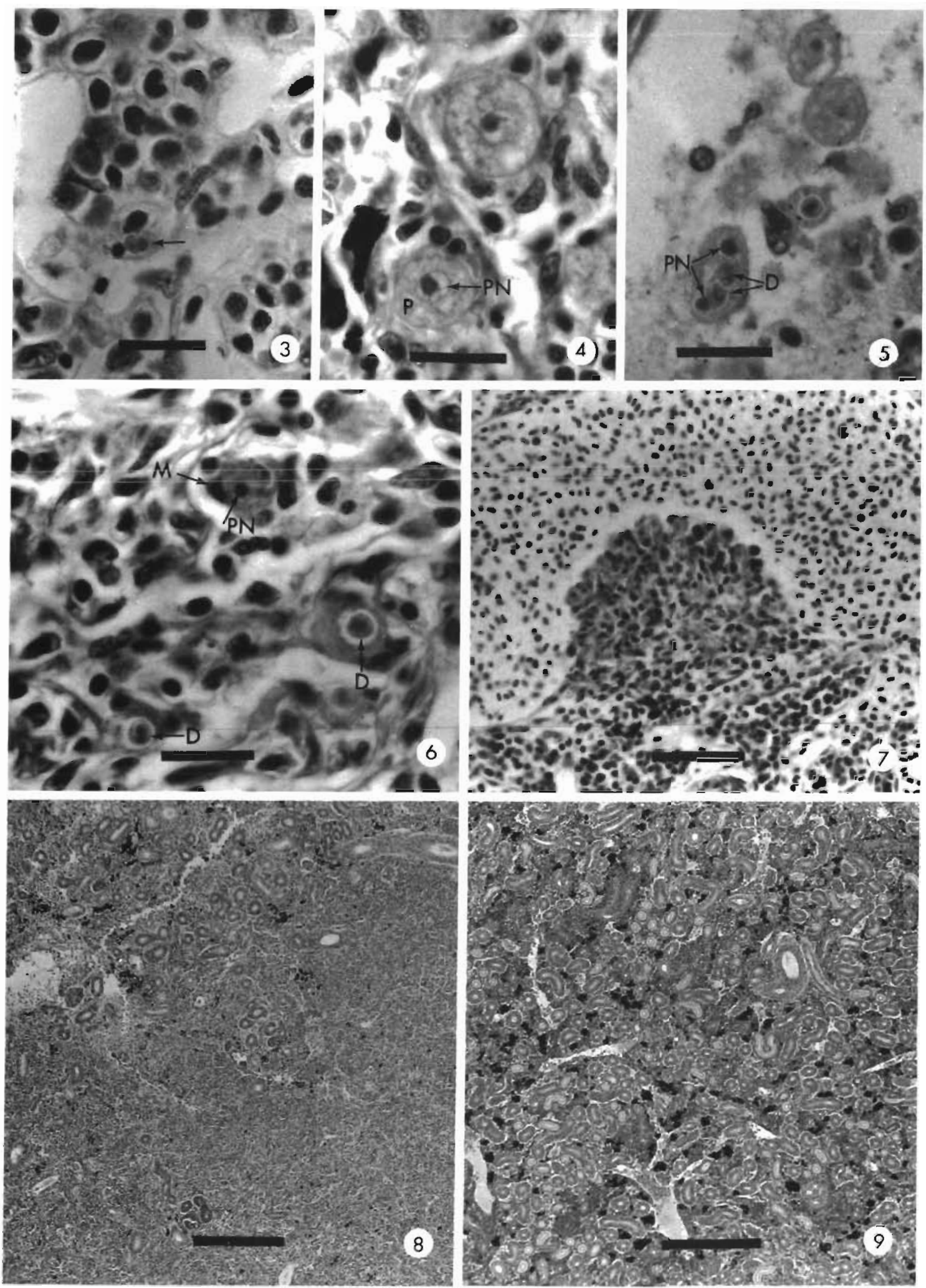

Fig. 3 to 18. Salmo gairdneri. Paraffin sections of PKX protozoans and intraluminal sporogonic forms in the kidneys. P: primary cell; PN: primary cell nucleus; D: daughter cells; $\mathrm{M}$ : macrophage; pc: polar capsules; $r$ : refractile granules. Bar $=10 \mu \mathrm{m}$ unless otherwise indicated. Fig. 3. Earliest recognized PKX in kidney at 3 wk after exposure. H \& E. Fig. 4. Uninucleate PKX parasites in the interstitium. H \& E. Fig. 5. Multicellular PKX in renal blood vessel. H \& E. Fig. 6. Degenerating PKX primary cells releasing daughter cells. H \& E. Fig. 7. Thrombus with PKX parasites in renal vessel. H \& E. Bar $=50$ um. Fig. 8. Interstitial hypercellularity, inflammation and tubular atrophy in the posterior kidney of PKD-affected trout. H \& E. Bar = 200um. Fig. 9 . Posterior kidney of a normal uninfected trout. H \& E. Bar $=200 \mu \mathrm{m}$ 

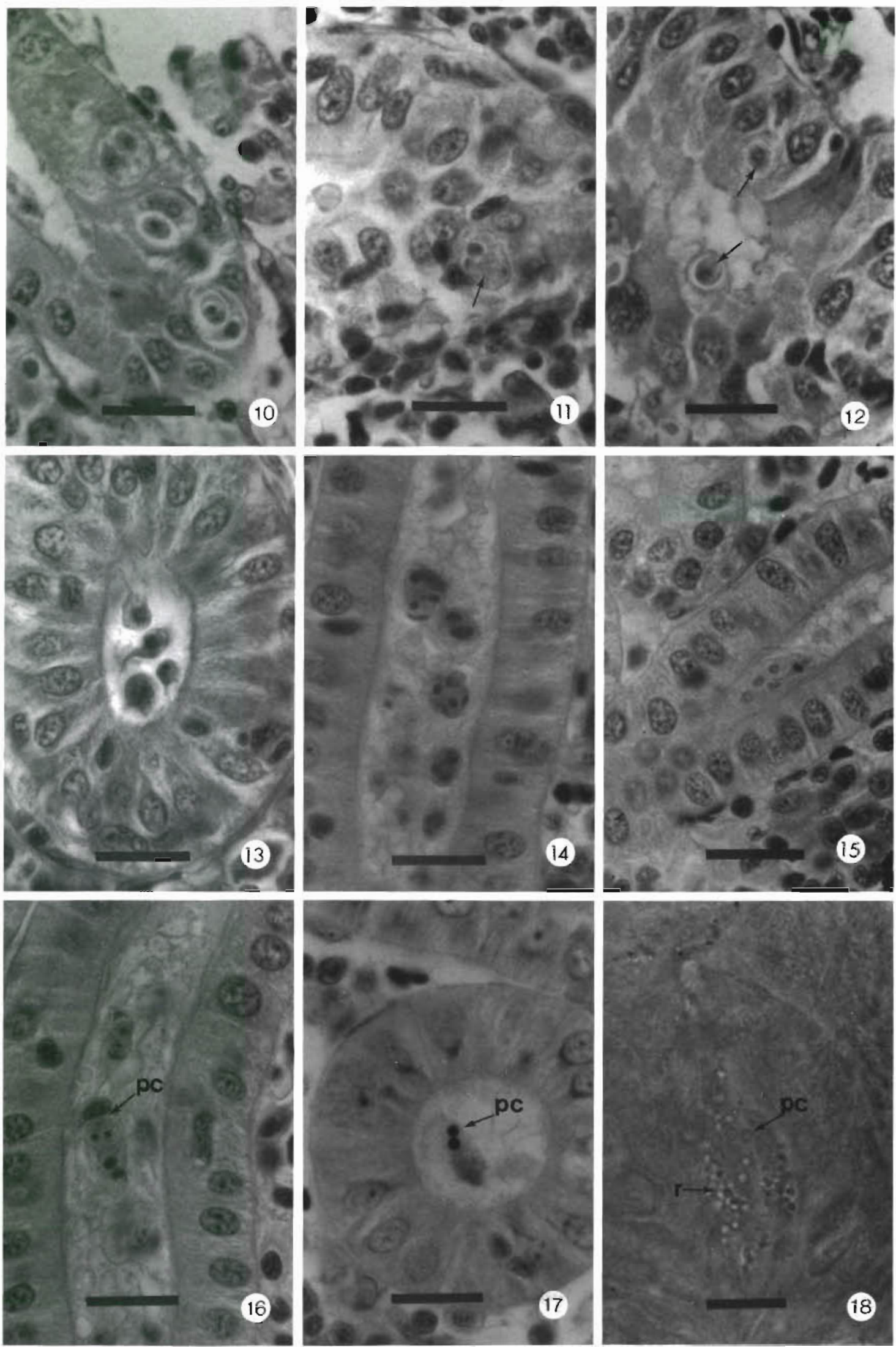

Fig. 10. Epithelium of a renal tubule with PKX. H \& E. Fig. 11. Secondary daughter cells dividing by binary fission (arrow) in the epithelium of a tubule. H \& E. Fig. 12. Daughter cells (arrows), surrounded by primary cell remnants, migrating to the lumen of a tubule. H \& E. Fig. 13. Early intraluminal cells. H \& E. Fig. 14. Intraluminal pseudoplasmodia with internal sporoblasts. H. \& E. Fig. 15. Intraluminal sporoblast with cell dividing by binary fission. $\mathrm{H} \&$ E. Fig. 16. Pseudoplasmodium with developing spore. $\mathrm{H}$ $\&$ E. Fig. 17. Developing spores in the lumen of a tubule. Giemsa. Fig. 18. Wet mount of kidney with intraluminal pseudoplasmodia with developing spores. Bar $=10 \mu \mathrm{m}$ 
plasmodia, typical of most myxosporeans, were observed. However, up to 3 nuclei were observed in some enveloping cells. This monosporous development within an enveloping cell, described as a 'pseudoplasmodium' by Lom et al. (1982) in Sphaerospora spp., was confirmed in wet mounts (Fig. 18). Enveloping cells observed in wet mounts were characterized by numerous refractile granules.

The spores apparently did not complete their development in the kidney. No clear spore valves or well defined valvogenic cells were observed in either paraffin sections or wet mounts. The spores were fragile and lacked rigidity as evidenced by the readiness with which they changed shape under pressure of the cover slip in wet mounts; they degenerated within $4 \mathrm{~h}$ in minced kidneys mainlained in water at $10^{\circ} \mathrm{C}$. Further, spores could no longer be detected after $24 \mathrm{~h}$ under these same conditions.

The intraluminal trophozoites and spores were most frequently observed in the second proximal and distal segments of the tubules. Although they were not found in the collecting ducts, ureters or urinary bladder, 3 sporoblasts with polar capsules were observed in one of 10 urine samples obtained from fish at the American River hatchery.

\section{Electron microscopy}

The primary cell of PKX often contained internal secondary and tertiary daughter cells (Fig. 19) and always contained 'haplosporosomes' identical to those described by Seagrave et al. (1980a, b) (Fig. 20). The primary cells contained a prominent endoplasmic reticulum. They also contained large, electron-dense, membrane-bound inclusions which were presumed to be secondary lysosomes. The daughter cells, either secondary or tertiary, were encircled by a membrane of the outer cell. They never contained haplosporosomes and rarely lysosomes. Degenerating primary cells, with condensed organelles and disrupted membranes, contained intact daughter cells (Fig.21). The latter may be released to continue the vegetative development of the parasite in the interstitium.

The PKX parasites in the epithelium of the tubules (Fig. 22) had an ultrastructural morphology identical to those in the interstitium. They migrated to the lumen by penetrating between the epithelial cells.

Daughter cells within PKX and early intraluminal forms had a similar ultrastructural morphology. The simplest and possibly earliest intraluminal forms were uninucleate (Fig. 23), and presumably they were daughter cells released from typical PKX. These forms and daughter cells within typical PKX shared a similar size, nucleus to cytoplasm ratio, chromatin pattern, and plate-like cristae in the mitochondria. Additionally, as with secondary cells, they contained little endoplasmic reticula compared to the primary cell of PKX, and had similar ribosome content and cytoplasmic matrices.

More complex intraluminal forms had enveloping cells with electron-dense multilaminate bodies and up to 5 sporogonic cells (Fig. $24 \& 25$ ). The most fully developed forms observed were spores containing polar capsules with coiled internal filaments (Fig. 26). Although valves were not observed, early valvogenic cells partially surrounded the capsulogenic cells.

Macrophages usually surrounded the parasites in the blood and kidney interstitium, but they were not observed in association with the intraluminal stages. The only intracellular stage of PKX observed was a small form that had been completely engulfed by a macrophage.

A diagramatic representation of the sequential development of PKX in the kidney of salmonid fishes is shown in Fig. 27. Stages represented were observed either by light or electron microscopy.

\section{DISCUSSION}

Evidence from this study verifies that $\mathrm{PKX}$ belongs to the phylum Myxozoa. Myxosporeans are ubiquitous, usually host-specific parasites of fishes (Mitchell 1977) and the prespore stages typically do not induce a significant inflammatory response (Dykova \& Lom 1978). Salmonids exhibit a severe inflammatory response to interstitial PKX, which is the presporogonic form, and only immature spores were observed. This suggests that salmonids are abnormal hosts for PKX.

Proliferative kidney disease parasites (PKX) with identical morphology to those reported by Ferguson \& Needham (1978), Seagrave et al. (1980a, b) and Smith et al. (1984) were frequently observed in the blood and kidney interstitium. The parasite was detected in fish introduced to water containing the infectious stage 1 wk earlier than previously reported (Ferguson \& Ball 1979, D'Silva et al. 1984), and at this time was smaller and more condensed than typical PKX (Fig. 3). Numerous typical forms were observed in the blood, particularly early in the infection, which may indicate that it reaches the kidney via the circulatory system.

The PKX parasite most likely undergoes vegetative reproduction within the fish host. This is supported by the observation of numerous daughter cells in the kidney interstitium of heavily infected fish (Fig. $5 \& 6$ ). Additionally, fish injected with very few parasites became heavily infected (Kent \& Hedrick 1985b). Fish transferred from the hatchery to PKX-free water at U.C. Davis before parasites could be detected later 

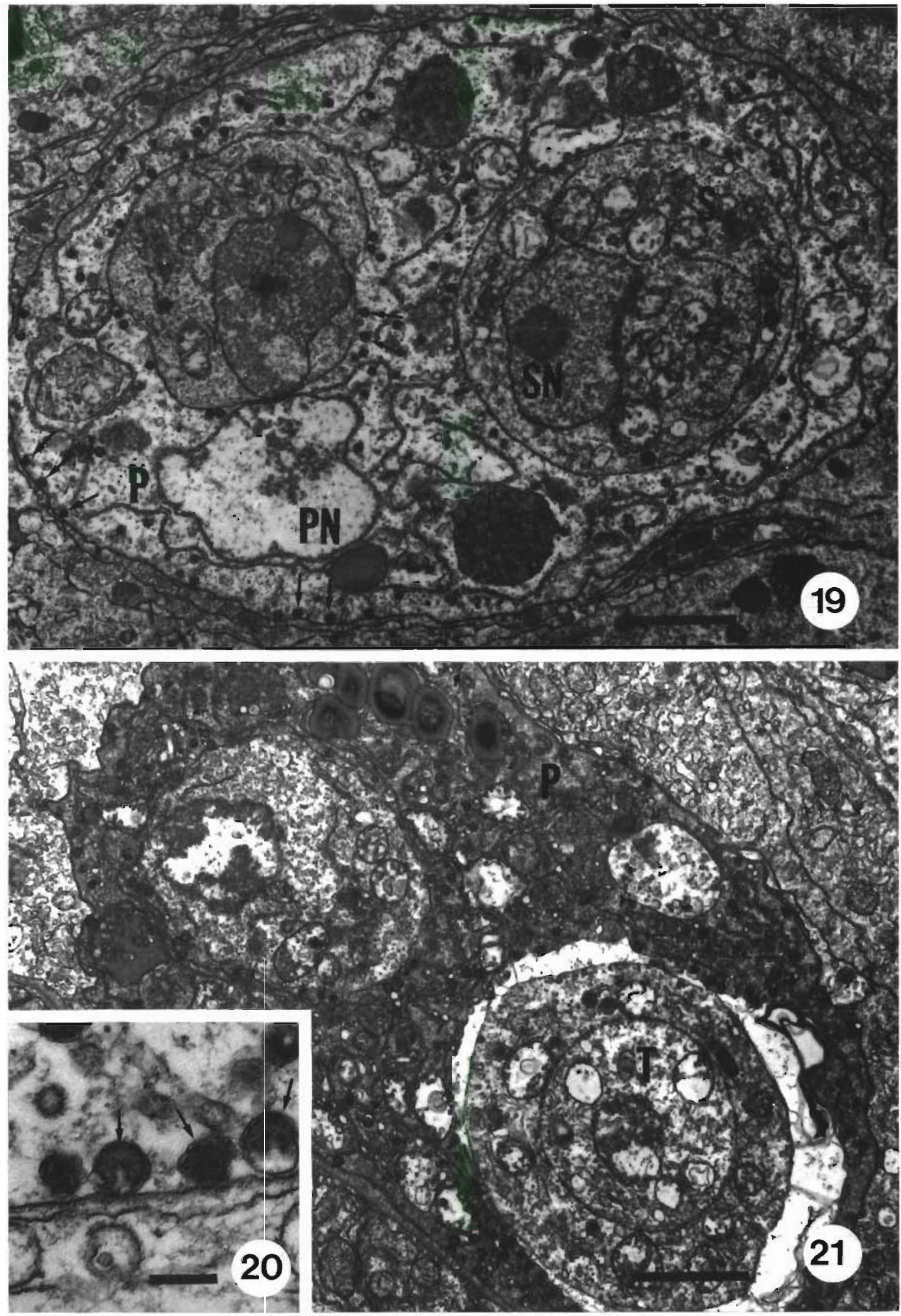

Fig. 19 to 25. Salmo gairdneri. Electron micrographs of typical PKX and intraluminal sporogonic forms in the kidney. P: primary cell; PN: primary cell nucleus; S: secondary cell; SN: secondary cell nucleus; $\mathrm{T}$ tertiary cell; arrows: haplosporosomes; pc: polar capsule; X: extended polar capsule filament; E: enveloping cell. Bar $=2 \mu \mathrm{m}$ unless otherwise indicated. Fig. 19. Interstitial PKX with 2 secondary cells. Haplosporosomes are confined to the primary cell. Fig. 20. Haplosporosomes in primary cell of interstitial PKX. Bar $=0.2 \mu \mathrm{m}$. Fig. 21. Degenerating primary cell with intact daughter cells in interstitium 

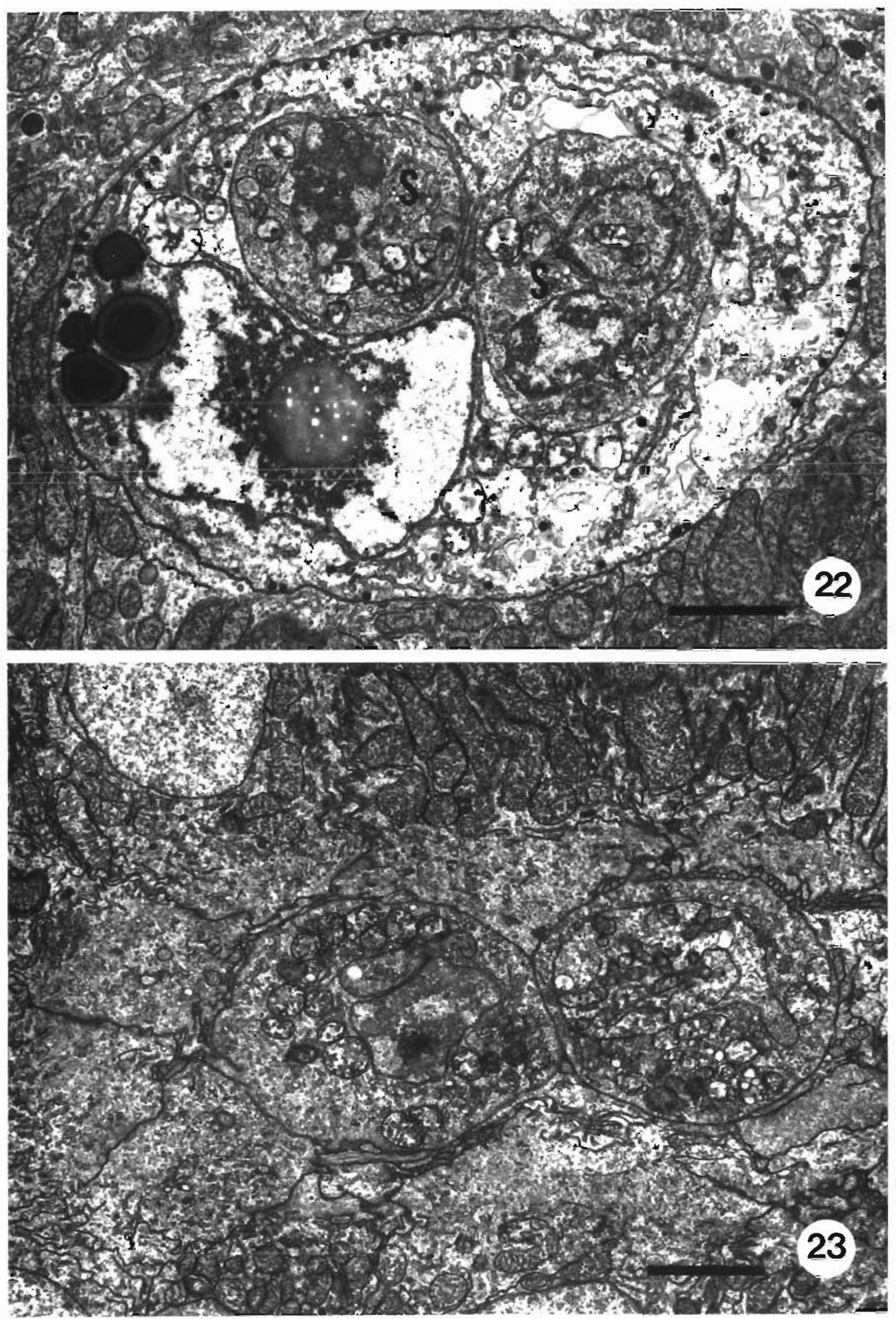

Fig. 22. Epithelium of a tubule with PKX. Fig. 23. Early intraluminal myxosporean stages in the lumen of a tubule 

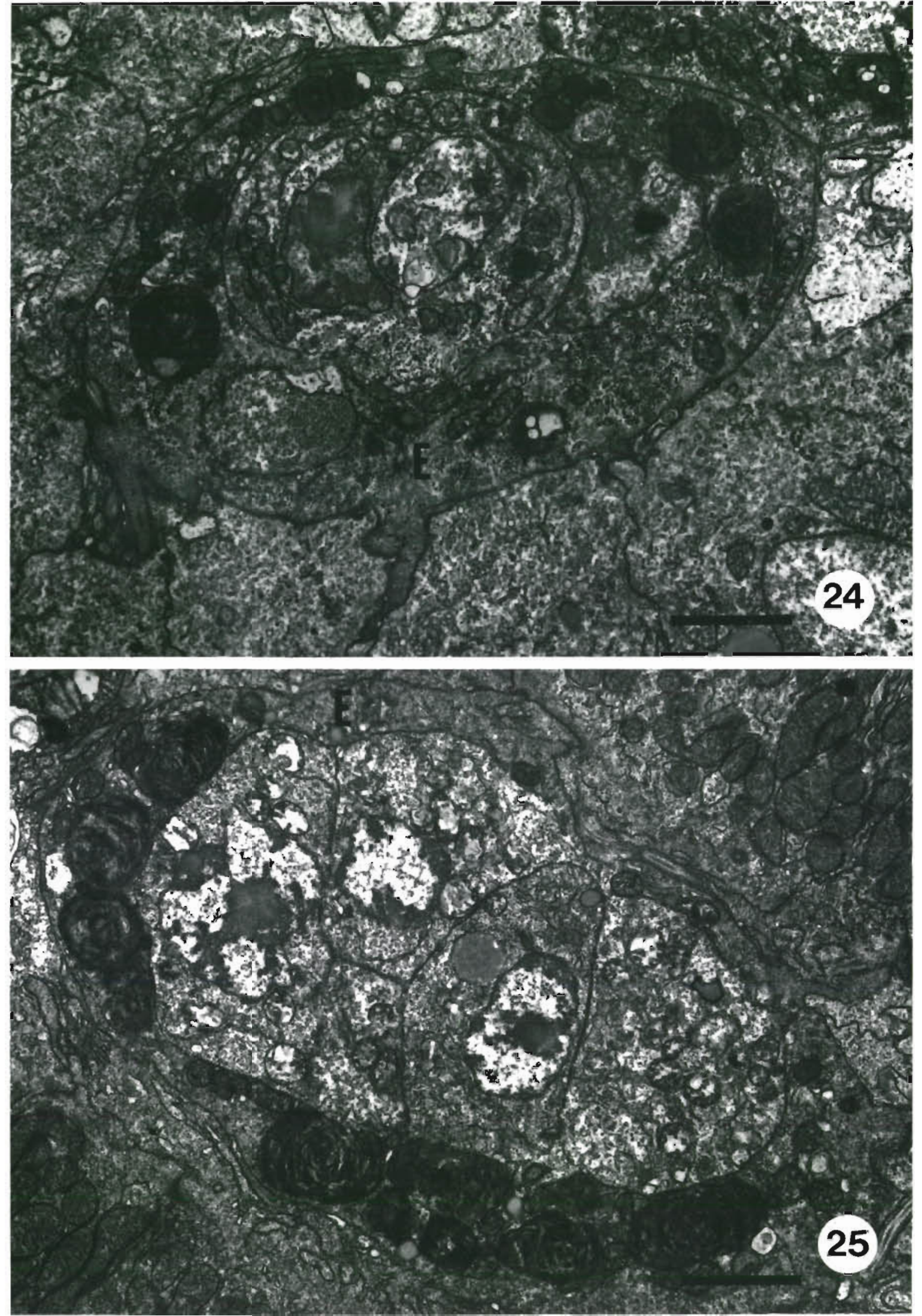

Fig. 24. Pseudoplasmodium with internal sporogonic cells in the lumen of a tubule. Fig. 25. Pseudoplasmodium with 5 sporogonic cells 


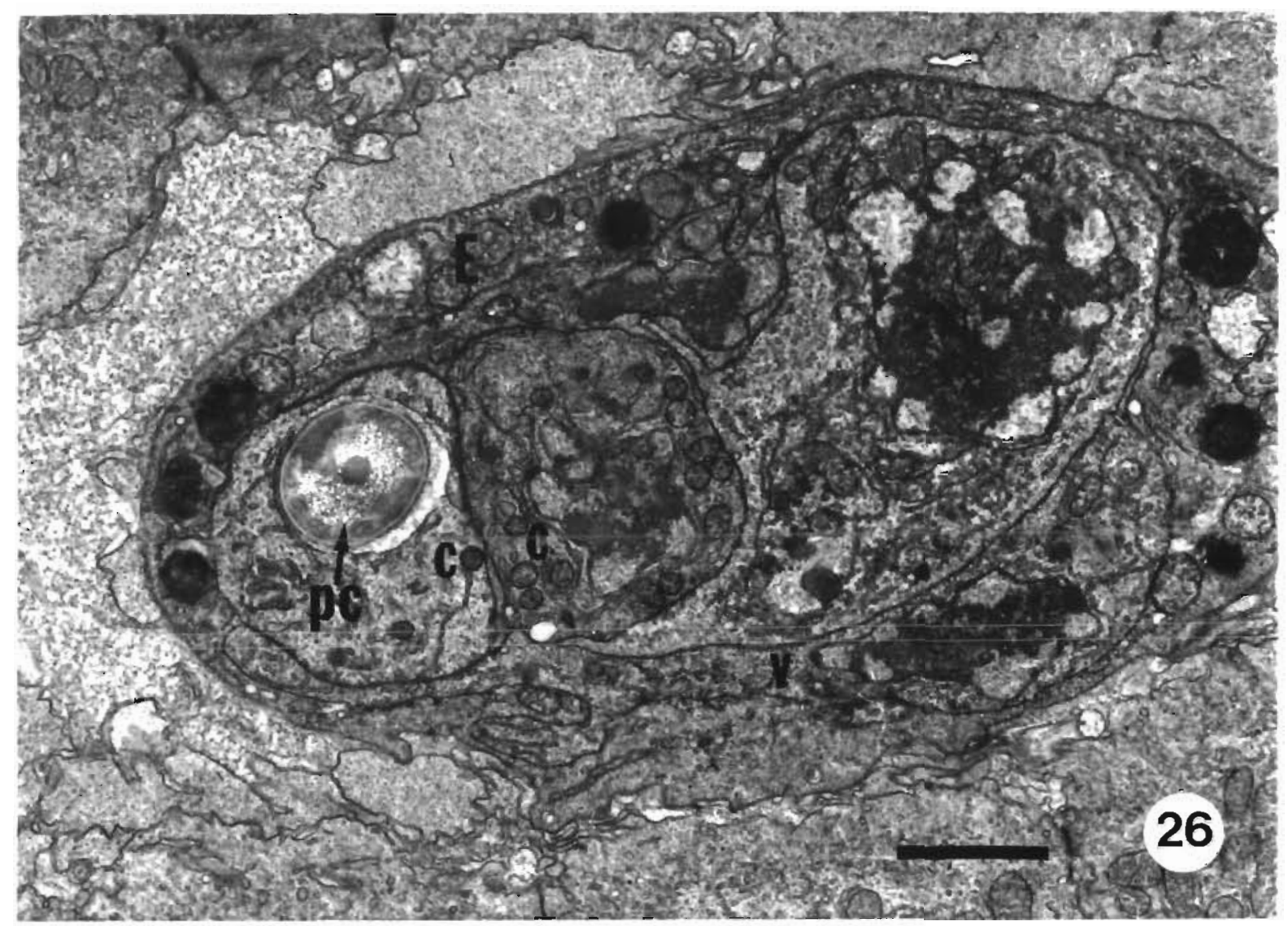

Fig. 26. Salmo gairdneri. Intraluminal sporoblast with polar capsules. Valvogenic cells (v) surrounding capsulogenic cells (c); pc: polar capsule; E: enveloping cell

developed heavy infections (Fig. 2), indicating that continual exposure is not needed to induce heavy infections. A mechanism for the development of the daughter cells by internal cleavage was reported by Seagrave et al. (1980b). However, binary fission of the internal daughter cells, as reported in the present study, is a second method for vegetative development. No fixed developmental sequence within the kidney interstitium could be determined, and plasmotomy (external budding), endogeny (internal budding), and binary fission may all occur in the same parasite (Fig. 27). This lack of rigidity in the vegetative development is consistent with the phylum Myxozoa (Lom et al. 1983a, Johnstone 1984).

Ferguson \& Needham (1978) reported PKX in the renal tubules, but migration of the parasite through the epithelium and release of daughter cells into the lumen were not described. The PKX parasites in the epithelium of the tubules and its intraluminal stages were more prevalent in convalescing fish than in clinically affected fish (Fig. 1), and Ferguson \& Needham (1978) have suggested that the tubules may provide a mode of exit for the parasite.

The simplest intraluminal stage detected in this study was a small unicellular organism. Similar forms contained single endogenous daughter cells (Fig. 23). These stages appeared identical to the internal daughter cells of the interstitial and epithelial PKX (Fig. 19 \& 22) and are most likely the same cells. Haplosporosomes are only observed in the primary cell of PKX (Ferguson \& Needham 1978, Seagrave et al. 1980a, Smith et al. 1984). This accounts for their absence in the intraluminal forms because this stage seems to arise from released secondary cells of typical PKX. The intraluminal forms represent pseudoplasmodia as described by Lom et al. (1982) for Sphaerospora spp. and the internal cells are the sporoblast. The enveloping cell of the pseudoplasmodium in Sphaerospora spp, is uninucleate (Lom et al. 1982), but this cell of PKX often contained 2 or 3 nuclei. This cell also contained prominent refractile granules as seen in wet mounts (Fig. 18), and these are most likely analogous to the electron-dense multilaminated bodies (Fig. 24 to 26) and the periodic acid Shiff's (PAS) positive bodies reported by Kent \& Hedrick (1985a). Polar capsule formation in PKX indicated spore formation. However, trophozoites were more numerous than spores, even late in the infection, as Bond (1938) reported for 
Sphaerospora renalis in the killifish Fundulus heteroclitus L.

Polar capsules may form before valvogenesis occurs, as in other myxosporeans (Desser \& Paterson 1978, Current et al. 1979), and valves were not apparent in the PKX spore. The spores remained within their pseudoplasmodium throughout the infections, and this, combined with the apparent lack of valves, indicates that the spores were not fully developed. Five to 6 sporogonic cells were observed in maturing sporoblasts, which is consistent with myxosporean sporogenesis. Two of the cells correspond to the capsulogenic cells, 1 or 2 to the sporoplasm cells, and 2 presumably to the valve-forming cells (Mitchell 1977). Although valves were not observed, PKX spores may form vestigial valvogenic cells in salmonids. These spores were fragile, and it is unlikely that they would survive long enough for valvogenesis to occur if they were released from this host.

Although many spores were observed by light microscopy, few were found by electron microscopy. In one spore, early valvogenic cells partially surrounded capsulogenic cells (Fig. 26). If more advanced stages of valvogenesis occur, they were not detected by light microscopy. More spores must also be examined by electron microscopy to identify the most advanced stage of spore development that occurs in salmonids.
Such studies are made difficult because of the paucity of PKX spores in most fish.

A clear sequential development from the interstitial PKX to spores with polar capsules demonstrated the myxosporean nature of the parasite. This is further supported by epizootiological evidence and experimental data. The myxosporean of this study was only observed in PKX-exposed fishes, and although it has not been reported previously, it was detected in kidney sections of infected fish from all cases of PKD that we have examined. These involved coho salmon Oncorhynchus kisutch (Walbaum) and steelhead trout from 2 enzootic areas on Vancouver Island, British Columbia, Canada; convalescing rainbow trout from the Hagerman State hatchery, Idaho, USA; coho salmon from the State of Washington, USA; and from all cases investigated in California, USA (Hedrick et al. 1984a, b, 1985). A similar myxosporean has been found in PKXexposed Atlantic salmon Salmo salar (L.) and brown trout Salmo trutta (L.) in Europe (R. S. Clifton-Hadley, Ministry of Aquaculture, Fisheries and Food, Weymouth, England, pers. comm.). The coincidence of typical PKX with the intraluminal myxosporean forms was further demonstrated in studies by Hedrick et al. (1985). Fish introduced to the American River hatchery during the spring and summer showed both typical PKX and the intraluminal forms. In contrast, fish exposed during

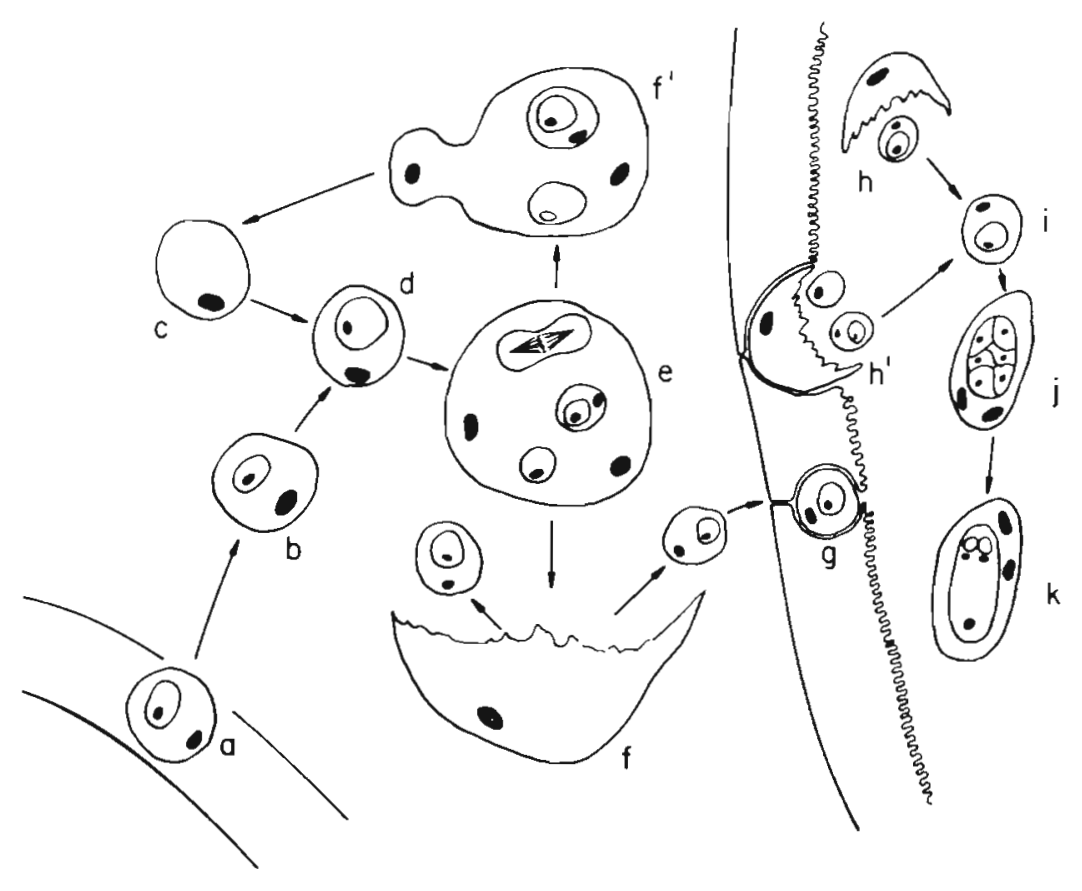

Fig. 27. Sequential development of PKX in kidney of salmonid fishes as interpreted from wet mounts, paraffin sections and electron micrographs. (a) PKX parasite in a blood vessel. (b) PKX enters kidney interstitium. (c) Uninucleate PKX. (d) Daughter cell produced by endogenous budding. (e) Secondary daughter cells divide by binary fission and produce tertiary cells by endogenous budding. Nuclear division in primary cell may also occur. (f) Daughter cells are released from degenerated primary cell and continue vegetative development. (f') Plasmotomy or binary fission of primary cell may also occur. Vegetative development also may occur in the blood vessels. (g) PKX parasite penetrates between epithelial cells of tubule. (h) PKX enters the lumen; primary cell degenerates and releases secondary cell (= pseudoplasmodium). ( $\mathrm{h}^{\prime}$ ) Primary cells may release daughter cells into lumen from epithelium. Multiplication of released secondary cells may occur in the lumen. (i) Released secondary cell (enveloping cell) with tertiary (sporogonic) cell. (j) Tertiary cell multiplies resulting in a multicellular sporoblast. (k) Sporulation continues; capsulogenic cells differentiate and form polar capsules and sporoplasm develops a prominent nucleus. No valvogenesis observed, and spore remains within enveloping cell throughout infection 
the winter when the infectious stage was not present did not become infected with either stage of PKX.

A blood and spleen transmission experiment by Kent \& Hedrick (1985b) also supports the conclusion that both forms belong to the same parasite. Fish injected with the blood and spleen of PKX-infected fish became infected with both interstitial PKX and the intraluminal myxosporeans. Since only the typical PKX is found in blood and spleen, the myxosporeans must have arisen from this stage.

Seagrave et al. (1980a) suggested that PKX is a haplosporidan (phylum Ascetospora) because of its similarities with the invertebrate pathogens Marteilia spp. However, they did not exclude the possibility that it may belong to the phylum Myxozoa. The higher taxonomy of these phyla is in a state of confusion. Desportes \& Ginsburger-Vogel (1977) demonstrated affinities of the family Marteiliidae with the class Paramyxea (Ascetospora), Actinosporea, and Myxosporea (Myxozoa), and suggested they be grouped in a common taxon. Of the myxosporeans examined by transmission electron microscopy, most form electron-dense cytoplasmic inclusions, similar to haplosporosomes in the Ascetospora (Current \& Janovy 1977, Desser \& Paterson 1978, Current et al. 1979, Lom et al. 1982, Desser et al. 1983), and organisms of both phyla reproduce by internal cleavage (endogenous budding).

Although the PKX myxosporean could not be identified because only immature spores were found, it shows similarities to Sphaerospora spp. (family Sphaerosporidae). Kent \& Hedrick (1985a) compared the prespore form of PKX in the kidney interstitium to a protozoan of carp blood (UBO), which may be an early stage of Sphaerospora renicola (Lom et al. 1983a). A protozoan similar to UBO found in the swimbladder of carp was shown to be an early stage of $S$. renicola (angulata) (Csaba et al. 1984, Molnár 1984). The PKX parasite is similar to UBO and the swimbladder protozoan in that all 3 form endogenous secondary and tertiary daughter cells which are released and may subsequently sporulate in the lumen of the tubules. As with PKX, the secondary cells of UBO reproduce by binary fission in addition to endogenous budding (Lom et al. 1983a). Furthermore, sporogenesis of PKX is similar to that of some Sphaerospora spp. in that spores of both are formed with a pseudoplasmodium in the lumen of the kidney tubules. The enveloping cell of pseudoplasmodium in both parasites contains prominent refractile granules (Lom et al. 1985), and PKX is monosporous like S. molnari (Lom et al. 1983b).

A comparison of immature spores of Sphaerospora spp. with those of PKX shows similar features such as an elongated shape, small polar capsules, and indistinct valves. In contrast to $\mathrm{PKX}$, the mature spores of Sphaerospora spp. have a spherical shape and valves are evident. Ferguson (1984) reported Sphaerosporalike myxosporeans in the kidneys of feral brown trout from PKD enzootic waters, and Lom et al. (1985) observed pseudoplasmodia without spores in brown trout and grayling in Czechoslovakia. These fishes are hosts for PKX, and the pseudoplasmodia were possibly the intraluminal stages of PKX.

Although the PKX myxosporean shows many similarities to members of the family Sphaerosporidae, its spore also resembles those described for Parvicapsula (Parvicapsulidae). Members of this genus are also elongated, and have 2 polar capsules similar in size to those of PKX. Furthermore, a Parvicapsula sp. is known to sporulate in the epithelium of the kidney tubules in coho salmon (Hoffman 1984, Johnstone 1984). Although Parvicapsula develops in the usual myxosporean manner with large plasmodia and pansporoblasts, it may also form pseudoplasmodia (J. Lom, Czechoslovak Academy of Sciences, C. Budéjovice, Branišovská, Czechoslovakia, pers. comm., Johnstone 1984).

Spore morphology has been the most important criterion for species descriptions in the Myxozaa (Mitchell 1977), but the origin of sporoblasts (either within true plasmodia or pseudoplasmodia) should also be included in these descriptions (Lom et al. 1982, Lom \& Noble 1984). Identification of the primary host and completely formed spores are needed before the precise taxonomic status of the PKX myxosporean can be determined.

Salmonids may be abnormal hosts for PKX (Seagrave et al. 1980a). The severe inflammation associated with the prespore (typical) PKX stage and the lack of complete development of the spore support this hypothesis. The severe inflammation with $\mathrm{PKD}$ is in contrast to the lack of tissue reaction to the prespore forms in hosts in which myxosporeans complete sporogenesis (Dyková \& Lom 1978). No significant pathological changes were associated with the intraluminal stages of PKX, and the interstitial nephritis disappeared shortly after the typical PKX form was no longer detectable (Fig. 1). Ferguson (1981) reported that fish with PKD recover faster in cold water. However, low temperatures are not required for disappearance of the interstitial $\mathrm{PKX}$, recovery from $\mathrm{PKD}$, migration of $\mathrm{PKX}$ to the tubules, or sporulation, because all of these events occurred in the fish transferred to U.C. Davis where temperatures remained above $15^{\circ} \mathrm{C}$

This suggests that the stage of development of the parasite is an important factor in the inflammatory response associated with $\mathrm{PKD}$. Furthermore, the inflammatory response in an abnormal host may inhibit the migration of $\mathrm{PKX}$ to the tubules and subsequent sporulation. Kent (1985) immunosuppressed PKXinfected fish with cortisol implants and found that suppression of the inflammatory response to PKX 
enhanced the development of the parasite. In PKXinfected fish with cortisol implants, more interstitial forms, but less interstitial hypercellularity were observed. These fish also exhibited more sporogonic stages, but the cortisol treatments did not induce complete development of the spores (Kent 1985, Kent \& Hedrick 1986). Possibly the kidney tubules of rainbow trout do not provide the proper physiological environment for complete sporulation. This is substantiated by the observations from fish in natural epizootics, in which spores persisted in an immature state in the tubules several months after the inflammation had subsided (Fig. 1).

This study has demonstrated that the causative agent of PKD is the presporogonic form of a myxosporean, which undergoes vegetative development and induces a severe tissue response in the kidney interstitium and blood of rainbow trout. As the disease progresses, the parasites migrate to the lumen of the kidney tubules and sporulate within a pseudoplasmodium. Although inflammation was not associated with these sporogonic forms, only immature spores were observed in the tubules. These observations all indicate that salmonids are abnormal hosts for PKX and that the parasite may complete sporulation in a non-salmonid fish. Identification of the primary host is needed to determine the precise identity of PKX and the reservoir of infection.

We have recently observed immature spores similar to those of PKX and more fully developed Sphaerospora spores in the lumens of kidney tubules from tui chub Gila bicolor (Girad) (Cyprinidae), and sticklebacks Gasterosteus aculeatus L. (Gasterosteidae), from watersheds where PKX is prevalent (Hedrick et al. 1986). Studies are underway to determine the association of these myxosporeans with PKX and the role of non-salmonids as reservoir hosts.

Acknowledgements. This work is a result of research sponsored in part by NOAA, National Sea Grant College Program, Department of Commerce, under Grant Number NA80AA-D00120, project number R/F-100, through the California Sea Grant College Program, and in part by the California State Resources Agency. The U.S. Government is authorized to reproduce and distribute for governmental purposes. The authors also thank R. Munn and P. Lee for assistance with the electron microscopy and Drs. J. Lom and C. Smith for their helpful advice. The assistance of the staff at California Fish and Game, Fish Disease Laboratory, and the American River hatchery was invaluable.

\section{LITERATURE CITED}

Bond, F. F. (1938). Cnidosporidia from Fundulus heteroclitus Lin. Trans. Am. microsc. Soc. 57 (2): 107-122

Bullock, A. M. (1978). Laboratory methods. In: Roberts, R. J. (ed.) Fish pathology. Bailliere-Tindall, London, p. 245-267 Clifton-Hadley, R. S., Bucke, D., Richards, R. H. (1984).
Proliferative kidney disease of salmonid fish: a review. J. Fish Dis. 7: 363-377

Clifton-Hadley, R. S., Richards, R. H., Bucke, D. (1985). The sequential pathological changes in proliferative kidney disease. In: Ellis, A. E. (ed.) Fish and shellfish pathology. Academic Press, London, p. 359-367

Csaba, G., Kovács-Gayer, E., Békési, L., Buscek, M., Szakolczai, J., Molnar, K. (1984). Studies into the possible protozoan aeitiology of swimbladder inflammation in carp fry. J. Fish Dis. 7: $39-56$

Current, W. L., Janovy, J. (1977). Sporogenesis in Henneguya exilis infecting the channel catfish: an ultrastructure study. Protistologica 13; 157-167

Current, W. L., Janovy, J., Knight, S. A. (1979). Myxosoma funduli Kudo (Myxosporida) in Fundulus kansae: ultrastructure of the plasmodium wall and of sporogenesis. J. Protozool. 26: 574-583

Desportes, I., Ginsburger-Vogel, T. (1977). Affinités du genre Marteilia, parasite de'Huitres (maladie des Abers) et du Crustacé Orchestia gammarella (Pallas), avec les Myxosporidies, Actinomyxides et Paramyxides. C. r. hebd. Séanc. Acad. Sci., Paris D 285: 1111-1114

Desser, S. S., Molnár, K., Horvath, I. (1983). An ultrastructural study of the myxosporeans, Sphaerospora angulata and Sphaerospora carassil, in the common carp, Cyprinus carpio L. J. Protozool. 30: 415 422

Desser, S. S., Paterson, W. B. (1978). Ultrastructural and cytochemical observations on sporogenesis of Myxobolus sp. (Myxosporida: Myxobolidae) from the common shiner Notropis cornutus. J. Protozool. 25: 314-326

D'Silva, J., Mulcahy, M. F., de Kinkelin, P. (1984). Experimental transmission of proliferative kidney disease in rainbow trout Salmo gairdneri Richardson. J. Fish Dis. 7: 235-240

Dyková, I., Lom, J. (1978). Histopathological changes in fish gills infected with myxosporidian parasites of the genus Henneguya. J. Fish Biol. 12: 197-202

Ferguson, H. W (1981). The effects of water temperature on the development of proliferative kidney disease in rainbow trout, Salmo gairdneri Richardson. J. Fish Dis. 4: $175-177$

Ferguson, H. W. (1984). Proliferative kidney disease in Northern Ireland: epidemiology and control. S. F. Sniesko Commemorative Workshop: Fish Health Sec./Am. Fish Soc. Ann. conf., Little Rock, Arkansas, 10-12 July, p. 6

Ferguson, H. W., Ball, H. J. (1979). Epidemiological aspects of proliferative kidney disease amongst rainbow trout Salmo gairdneri Richardson in Northern Ireland. J. Fish Dis. 2: 219-225

Ferguson, H. W., Needham, E. A. (1978). Proliferative kidney disease in rainbow trout Salmo gairdneri Richardson. J. Fish Dis. 1: 91-108

Ghittino, P., Andruetto, S., Vigliani, E. (1977). Lamebiasi della trota iridea d'Allevamento. Riv. ital. Piscic. Itiopathol. 12: 74-89

Hedrick, R. P., Kent, M. L., Rosemark, R., Manzer, D. (1984a). Proliferative kidney disease (PKD) in Pacific salmon and steelhead trout. J. World Maricul. Soc. 15: 318-325

Hedrick, R. P., Kent, M. L., Rosemark, R., Manzer, D. (1984b). Occurrence of proliferative kidney disease (PKD) among Pacific salmon and steelhead trout. Bull. Eur. Ass. Fish Pathol. 4 (3): 34-37

Hedrick, R. P., Kent, M. L., Foott, M. S., Rosemark, R., Manzer D. (1985). Proliferative kidney disease among salmonid fish in California, USA; a second look. Bull. Eur. Ass. Fish Pathol. 5 (1): 36-38

Hedrick, R. P., Kent, M. L., Toth, R. J. (1986). Myxosporeans found in the kidneys of non-salmonid fish from waters 
enzootic for proliferative kidney disease (PKD). Fish Health Sec./Am. Fish. Soc. Newsletter 14 (2): 4

Hoffman, G. L. (1984). Two fish pathogens, Parvicapsula sp. and Mitraspora cyprini Myxosporea, new to North America. Symp. Biol. Hung. 23: 127-135

Hoskins, G. (1985). In brief notes. Fish Health Sec./Am. Fish. Soc. Newsletter $13(1): 8$

Humason, G. L. (1979). Animal tissue techniques. W. H. Freeman Co., San Francisco

Johnstone, A. K. (1984). Pathogenesis and life cycle of the myxozoan Parvicapsula sp. infecting marine cultured coho salmon. Doctoral dissertation, Univ, of Washington

Kent, M. L. (1985). The development of the PKX myxosporean, the causative agent of proliferative kidney disease, in rainbow trout Salmo gairdneri Richardson. Doctoral dissertation, Univ. of California, Davis

Kent, M. L., Hedrick, R. P. (1985a). PKX, the causative agent of proliferative kidney disease (PKD) in Pacific salmonid fishes and its affinities with the Myxozoa. J. Protozool. 32: 254-260

Kent, M. L., Hedrick, R. P. (1985b). Transmission of the causative agent of proliferative kidney disease with the blood and spleen of infected fish; further evidence that the PKX parasite belongs to the phylum Myxozoa. Bull. Eur. Ass. Fish Pathol. 5 (2): 39-42

Lom, J., Dyková, I., Lhotáková, S. (1982). Fine structure of Sphaerospora renicola Dyková and Lom, 1982, a myxosporean from carp kidney and comments on the origin of pansporoblasts. Protistologica 18: 489-502

Lom, J., Dyková, I., Pavlásková, M. (1983a). 'Unidentified' mobile protozoans from the blood of carp and some unsolved problems of the myxosporean life cycles. J. Protozool. 30: $497-508$

Lom, J., Dyková, I., Pavlásková, M., Grupcheva, G. (1983b).
Sphaerospora molnari sp, nov. (Myxozoa : Myxosporea), an agent of gill, skin and blood sphaerosporosis of common carp in Europe. Parasitology 86: 529-535

Lom, J., Noble, E. R. (1984). Revised classification of the class Myxosporea Bütschli, 1881. Folia Parasitol. (Praha) 31: 193-205

Lom, J., Pavlásková, M., Dyková, I. (1985). Notes on kidneyinfecting species of the genus Sphaerospora Thelohan (Myxosporea), including a new species $S$ gobionis $\mathrm{sp}$. nov., and myxosporean life cycle stages in the blood of some freshwater fish. J. Fish Dis. 8: 221-232

Luna, L. G. (1968). Manual of histologic staining. McGrawHill, New York

Mitchell, L. G. (1977). Myxosporidia. In: Krier, J. P. (ed.) Parasitic protozoa. Vol. IV. Academic Press, New York, p. 115-154

Molnár, K. (1984). Experimental evidence that protozoans causing swim-bladder inflammation in common carp (Cynrinus rarpio L) are stages of Sphaerospora renicola. Bull. Eur. Ass. Fish Pathol. 4: 14-15

Plehn, M. (1924). Praktikum der Fischkrankheiten. E. Schweizerbart'sche Verlagsbuchhandlung, Stuttgart

Seagrave, C. P., Bucke, D., Alderman, D. J. (1980a). Ultrastructure of a haplosporean-like organism: the possible causative agent of proliferative kidney disease in rainbow trout. J. Fish Biol. 16: 453-459

Seagrave, C., Bucke, D., Alderman, D. (1980b). The causative agent of proliferative kidney disease may be a member of the Haplosporidia. In: Ahne, W. (ed.) Fish diseases, Third COPRAQ Session. Springer-Verlag, Heidelberg, Berlin, p. 174-181

Smith, C. E., Morrison, J. K., Ramsey, H. W., Ferguson, H. W. (1984). Proliferative kidney disease: first reported outbreak in North America. J. Fish Dis. 7: 207-216

Responsible Subject Editor: Dr. T. Evelyn; accepted for printing on June 30, 1986 